\title{
Hubungan kadar HbA1c terhadap laju filtrasi glomerulus dan proteinuria pada penderita diabetes melitus tipe 2
}

\author{
Fahmi Majid ${ }^{1, *}$, Willy Brodus Uwan², Mistika Zakiah ${ }^{3}$ \\ ${ }^{1}$ Program Studi Kedokteran, Fakultas Kedokteran Universitas Tanjungpura, Kalimantan Barat, Indonesia \\ ${ }^{2}$ Bagian Ilmu Penyakit Dalam, RSU Santo Antonius, Kalimantan Barat, Indonesia \\ ${ }^{3}$ Departemen Farmakologi, Fakultas Kedokteran Universitas Tanjungpura, Kalimantan Barat, Indonesia \\ * Korespondensi: fahmi.majid007@gmail.com
}

\begin{abstract}
Abstrak
Latar belakang: Diabetes melitus merupakan suatu penyakit metabolik dengan karakteristik berupa hiperglikemia yang terjadi karena kelainan sekresi insulin, kerja insulin ataupun keduanya. Salah satu cara mengetahui kontrol glukosa darah adalah HbA1c, semakin tinggi kadarnya maka risiko komplikasi juga meningkat pada pasien diabetes melitus tipe 2. Nefropati diabetik adalah salah satu komplikasi diabetes melitus yang ditandai dengan penurunan laju filtrasi glomerulus (LFG) dan proteinuria. Penelitian ini bertujuan untuk mencari hubungan antara kadar HbA1c dan fungsi ginjal berdaasarkan LFG dan proteinuria pada penderita diabetes melitus tipe 2. Metode: Penelitian ini menggunakan metode potong lintang. Subjek adalah 51 penderita diabetes melitus di Rumah Sakit Umum St. Antonius Pontianak yang dipilih dengan cara consecutive sampling. Data diperoleh melalui anamnesis, data laboratorium dan data rekam medik pasien. Hasil: Uji statistik korelatif koefisien kontingensi menunjukkan hubungan antara HbA1c dan LFG dengan nilai $\mathrm{p}=0.431$ dan $\mathrm{r}=0,226$ dan hubungan antara HbA1c dan proteinuria dengan nilai $p=0.450$ dan $r=0.222$. Kesimpulan: Tidak terdapat hubungan yang bermakna antara kadar HbA1c dan fungsi ginjal berdasarkan LFG dan proteinuria pada penderita diabetes melitus tipe 2.
\end{abstract}

Kata kunci: diabetes melitus, HbA1c, LFG, proteinuria, fungsi ginjal

\section{Correlation between HbA1c and glomerular filtration rate and proteinuria in patients with type 2 diabetes mellitus}

\begin{abstract}
Background: Diabetes mellitus is a metabolic disease characterized by hyperglycemia c abnormalities of insulin secretion, insulin action, or both. One of the parameters in measuring the control of blood glucose is HbA1c. Higher levels mean a higher risk of complications in type 2 diabetes patients. Diabetic nephropathy is one of those complications marked by decreased glomerular filtration rate (GFR) and proteinuria. This research aimed to evaluate correlation between HbA1c and kidney function based on glomerulus filtration rate GFR and proteinuria. Methods: This research used cross-sectional method. Fifty one patients with diabetes melitus in St. Antonius General Hospital Pontianak were selected using consecutive sampling method. Data were obtained by anamnesis, laboratory data and medical record. Results: The coefficient of contingency test results showed the correlation of $\mathrm{HbA1c}$ and GFR with $\mathrm{p}$ value $=0,431$ and $\mathrm{r}=0,226$ and the correlation between HbA1c and proteinuria with $\mathrm{p}$ value $=0,450$ and $\mathrm{r}=0,222$. Conclusions. There was no significant correlation between HbA1c and kidney function based on GFR and proteinuria.
\end{abstract}

Keywords: diabetes mellitus, HbA1c, GFR, proteinuria, kidney function

Pendahuluan

Diabetes melitus (DM) adalah suatu penyakit kronik yang terjadi oleh karena kurangnya insulin yang dihasilkan pancreas (defisiensi insulin) atau gangguan efektifitas insulin (resistensi insulin). ${ }^{1}$ Diabetes melitus dibagi dalam 2 kelompok besar, yaitu tipe 1 dan tipe 2. Diabetes melitus tipe 2 adalah 
kelompok kelainan heterogen yang ditandai oleh variabel derajat resistensi insulin, sekresi insulin terganggu, dan peningkatan produksi glukosa. ${ }^{2}$ Data International Diabetes Foundation (IDF) tahun 2015 menempatkan Indonesia di peringkat tujuh untuk negara dengan penderita DM terbanyak di dunia yang mencapai 10 juta jiwa. ${ }^{3}$ Diabetes melitus adalah salah satu penyakit yang kurang terdiagnosis, dimana $30 \%$ pasien dengan DM tidak menyadari penyakitnya saat penegakan diagnosis dengan $25 \%$ di antaranya telah terjadi komplikasi pada mikrovaskular. Pengecekan HbA1c dapat dipilih sebagai salah satu modalitas untuk skrining, diagnosis, maupun kontrol pada DM. ${ }^{4} \mathrm{HbA} 1 \mathrm{c}$ merupakan istilah yang dipakai secara internasional untuk haemoglobin terglikasi. Kadar HbA1c sebagaimana dalam beberapa penelitian merupakan indeks rerata glukosa darah dalam jangka waktu minggu hingga bulan. ${ }^{5}$ Dalam jangka waktu tertentu diabetes dapat mempengaruhi berbagai sistem organ dalam tubuh sehingga menimbulkan komplikasi. Komplikasi dari diabetes terdiri dari komplikasi akut dan kronik. Komplikasi kronik dari diabetes dapat dibedakan menjadi dua kelompok besar yaitu makrovaskular dan mikrovaskular, salah satu komplikasinya adalah nefropati diabetik. Angka kejadian nefropati dibetik secara global pada orang dewasa diperkirakan meningkat dari 6,4\% (285 juta) pada 2010 menjadi $7,7 \%$ (439 juta) pada $2030 .{ }^{6}$ Deteksi dini yang dapat terlihat pada nefropati diabetik adalah albuminuria persisten (mikroalbuminuria) dan dapat dilihat dari laju filtrasi glomerulus. ${ }^{7}$

\section{Metode}

Penelitian ini merupakan penelitian analitik dengan rancangan cross-sectional yang dilakukan di RSU St. Antonius Kota Pontianak. Waktu pelaksanaan penelitian ini dari bulan Desember 2016-September 2017. Populasi pada penelitian ini adalah penderita DM tipe 2 yang berobat di RSU St. Antonius Kota Pontianak yang memenuhi kriteria inklusi berupa Pasien DM tipe 2 yang berusia di atas 40 tahun dan telah melakukan pengecekan kadar HbA1c. Pasien DM tipe 2 dengan hematuria, infeksi saluran kemih, batu saluran kemih, dan pasien DM tipe 2 yang datanya tidak lengkap merupakan kriteria eksklusi dalam penelitian ini.

Variabel bebas dalam penelitian ini adalah kadar HbA1c dan variabel tergantungnya adalah LFG dan proteinuria. Sampel yang digunakan sebanyak 51 penderita DM. Data tersebut diperoleh melalui anamnesis, laboratorium, dan rekam medis RSU St. Antonius Kota Pontianak yang dilakukan secara consecutive sampling.

Hasil yang akan diambil dalam penelitian ini berupa nilai HbA1c, usia, jenis kelamin, LFG dan proteinuria pasien DM tipe 2 di Rumah Sakit Umum St. Antonius di Kota Pontianak. Teknik analisis data yang digunakan adalah uji univariat dan uji bivariat dengan menggunakan uji korelatif koefisien kontingensi.

\section{Hasil}

\section{Distribusi subjek penelitian berdasarkan usia}

Pada penelitian didapatkan kelompok usia paling banyak pada 40-50 tahun dengan jumlah 22 pasien $(43,10 \%)$, sedangkan paling sedikit adalah kelompok usia 61-70 tahun dengan jumlah 10 pasien $(19,60 \%)$.

\section{Distribusi subjek penelitian berdasarkan jenis kelamin}

Pada penelitian ini didapatkan subjek penelitian dengan jenis kelamin laki-laki lebih banyak daripada perempuan. Subjek penelitian berjenis kelamin laki-laki sebanyak 29 orang $(56,90 \%)$, sedangkan subjek penelitian berjenis kelamin perempuan sebanyak 22 orang $(43,10 \%)$.

\section{Distribusi subjek penelitian berdasarkan kadar HbA1c}

Pada penelitian ini didapatkan pasien dengan kadar HbA1c tidak terkontrol lebih banyak daripada subjek penelitian dengan kadar HbAlc yang terkontrol. Subjek penelitian dengan kadar HbA1c tidak terkontrol sebanyak 42 orang $(82,40 \%)$, sedangkan subjek penelitian dengan nilai $\mathrm{HbA} 1 \mathrm{c}$ terkontrol sebanyak 9 orang $(17,60 \%)$.

\section{Distribusi subjek penelitian berdasarkan LFG}

Pada penelitian ini didapatkan pasien paling banyak memiliki $\mathrm{LFG} \geq 90 \mathrm{~mL} /$ menit dengan jumlah 18. Sedangkan yang paling sedikit yaitu pasien dengan kadar LFG 15-29 mL/menit dengan jumlah 8.

\section{Distribusi subjek penelitian berdasarkan proteinuria}

Pada penelitian ini didapatkan bahwa jumlah paling banyak adalah pada subjek dengan 
proteinuria positif 1 (+) yaitu sebanyak 20 pasien. Subjek paling sedikit adalah subjek dengan proteinuria positif $3(+++)$ yaitu sebanyak 4 pasien. Pada penelitian ini juga didapatkan subjek dengan proteinuria negatif (-) yaitu sebanyak 18 orang.

\section{Hubungan antara kadar HbA1c dan LFG}

Analisis bivariat dilakukan untuk mencari hubungan antara kadar Glycosylated Hemoglobin (HbA1c) dan LFG pada penderita diabetes melitus tipe 2. LFG pada penelitian digunakan sebagai skrining untuk menunjukkan adanya komplikasi nefropati diabetik pada pasien. Analisis bivariat pada penelitian ini dilakukan dengan menggunakan uji korelatif koefisien kontingensi.

Uji hipotesis yang dilakukan dengan menggunakan uji korelatif koefisien kontingensi didapatkan nilai $\mathrm{p}=0,431 \quad(\mathrm{p}>0,05)$ yang berarti kadar HbA1c dan LFG korelasinya tidak bermakna secara statistik. Nilai koefisien korelasi (r) sebesar $0,226(0<\mathrm{r} \leq 0,25)$ menunjukkan kekuatan korelasi yang sangat lemah dan tidak bermakna secara klinis.

\section{Hubungan antara kadar HbA1c dan proteinuria}

Analisis bivariat dilakukan untuk mencari korelasi kadar HbA1c dan proteinuria pada penderita DM tipe 2. Proteinuria pada penelitian digunakan sebagai skrining untuk menunjukkan adanya komplikasi nefropati diabetik pada pasien. Analisis bivariat pada penelitian ini dilakukan dengan menggunakan uji korelatif koefisien kontingensi.

Uji hipotesis yang dilakukan dengan menggunakan uji korelatif koefisien kontingensi didapatkan nilai $\mathrm{p}=0,450(\mathrm{p}>0,05)$ sehingga kadar $\mathrm{HbA1c}$ dan proteinuria korelasinya tidak bermakna secara statistik. Nilai koefisien korelasi (r) sebesar $0,222 \quad(0<\mathrm{r} \leq 0,2)$ menunjukkan kekuatan korelasi yang sangat lemah dan tidak bermakna secara klinis.

\section{Pembahasan}

\section{Hubungan antara kadar HbA1c dan LFG}

Uji hipotesis yang dilakukan adalah uji korelatif koefisien kontingensi dengan hasil yang didapatkan yaitu nilai $\mathrm{p}=0,450$ dan $\mathrm{r}=0,222$. Nilai $\mathrm{p}$ adalah nilai yang menunjukkan korelasi, jika nilai $\mathrm{p}>0,05$ maka H0 diterima dan $\mathrm{p}<0,05$ maka H0 ditolak. ${ }^{13}$ Nilai $\mathrm{p}$ sebesar 0,450 pada penelitian ini bermakna bahwa Ho diterima dan $\mathrm{H} 1$ ditolak. Ho yang diterima menyatakan hubungan atau korelasi antara kadar HbA1c dan kadar LFG tidak bermakna secara statistik $(\mathrm{p}>0,05) . \quad$ Nilai $\mathrm{r}$ sebesar 0,222 menunjukkan hubungan positif dari kedua variabel dengan kekuatan korelasi yang sangat lemah yaitu $0,0<\mathrm{r} \leq 0,25$. Korelasi positif menyatakan bahwa semakin tinggi variabel A maka semakin tinggi pula variabel $\mathrm{B}^{13}$

Hasil ini sejalan dengan penelitian Gahung et al dengan nilai $\mathrm{p}=0,462$ dan nilai korelasi 0,093 sehingga hubungan HbA1c dengan LFG tidak bermakna ${ }^{13}$ Hasil tersebut tidak berbeda dengan penelitian oleh Rigalleu dengan korelasi positif ( $\mathrm{r}=$ 0,29) antara HbA1c dan LFG. ${ }^{14}$ Studi National Health and Nutrition Examination Survey III mendapatkan pada $30 \%$ pasien Diabetes Melitus Tipe 2 memiliki LFG yang menurun. Beberapa proses dapat mengakibatkan penurunan LFG, yaitu Peningkatan tekanan hidrostatis pada kapsula bowman akan menurunkan LFG, peningkatan tekanan osmotik koloid pada kapiler glomerulus, dan aktifitas sistem saraf simpatis. Peningkatan tekanan hidrostatis dapat menyebabkan penurunan LFG yang serius, contohnya pada kasus batu saluran kemih. ${ }^{15}$ Hal yang dapat menyebabkan tidak terdapatnya hubungan antara kadar HbAlc dan LFG pada penelitian adalah tidak adanya kontrol terkait faktor perancu berupa risiko penyakit lain seperti batu saluran kemih yang tidak berhubungan dengan DM tipe 2. Pasien dengan Penyakit Ginjal Kronis mungkin menunjukkan kadar HbA1c normal karena gambaran yang ditunjukkan adalah kontrol selama 3 bulan sebagaimana penelitian oleh Andik Sunaryanto dari Rumah Sakit Umum Sanglah Denpasar. Pada pasien dengan Penyakit Ginjal Kronis stadium lanjut dapat terjadi penurunan glukosa maupun hemoglobin darah sehingga $\mathrm{HbA} 1 \mathrm{c}$ dapat terdeteksi normal. ${ }^{10}$

Baku emas dalam pengukuran LFG adalah pemeriksaan inulin klirens, sedangkan dalam penelitian ini pengukuran yang digunakan adalah formula Cockcroft-Gault yaitu perhitungan konversi kadar kreatinin serum menjadi LFG. Kreatinin memiliki beberapa kelemahan dalam pengukuran LFG. Kreatinin serum dapat dipengaruhi oleh beberapa faktor seperti massa otot, konsumsi daging, dan konsumsi obat-obatan seperti cimetidine. Kadar kreatinin serum juga dianggap stabil sehingga tidak sensitive oleh perubahan yang cepat dari fungsi ginjal. Faktor-faktor tersebut dapat mempengaruhi hasil penelitian sehingga dapat menyebabkan hubungan yang tidak signifikan. 
Desain penelitian cross-sectional merupakan desain yang sulit untuk menentukan sebab dan akibat dikarenakan pengambilan sampel yang dilakukan pada satu waktu yang bersamaan sehingga desain ini tidak tepat jika digunakan pada penelitian yang membutuhkan waktu cukup lama atau bersifat korelatif.

\section{Hubungan antara kadar HbA1c dan proteinuria}

Uji hipotesis yang dilakukan adalah uji korelatif koefisien kontingensi dengan hasil yang didapatkan yaitu nilai $\mathrm{p}=0,477$ dan $\mathrm{r}=0,216$. Nilai $\mathrm{p}$ adalah nilai yang menunjukkan korelasi, jika nilai $\mathrm{p}>0,05$ maka H0 diterima dan $\mathrm{p}<0,05$ maka H0 ditolak. ${ }^{13}$ Nilai $\mathrm{p}$ sebesar 0,450 pada penelitian ini bermakna bahwa Ho diterima dan $\mathrm{H} 1$ ditolak. Ho yang diterima menyatakan hubungan atau korelasi antara kadar HbA1c dan proteinuria tidak bermakna secara statistik $\quad(p>0,05) . \quad$ Nilai $r \quad$ sebesar 0,216 menunjukkan hubungan positif dari kedua variabel dengan kekuatan korelasi yang sangat lemah yaitu $0,0<\mathrm{r} \leq 0,25$. Korelasi positif menyatakan bahwa semakin tinggi variabel A maka semakin tinggi pula variabel B. ${ }^{13}$

Hasil ini sejalan dengan penelitian oleh $\mathrm{M}$. Afkhami et al yang mendapatkan hasil bahwa tidak terdapat hubungan yang signifikan antara $\mathrm{HbA1c}$ dan mikroalbuminuria $\mathrm{p}=0,571$ yang merujuk kepada proteinuria. Banyaknya protein dalam urin dan komposisinya bergantung pada kerusakan ginjal yang menyababkan kehilangan protein. ${ }^{5}$ Nefropati diabetik klinis yang ditandai dengan adanya proteinuria akan terjadi setelah 10-15 tahun seseorang menderita DM. Pada tahap awal nefropati masih asimptomatik dan belum ditemukan proteinuria sehingga lama pasien menderita DM dapat berpengaruh terhadap hasil penelitian. ${ }^{8}$

Pengecekan proteinuria pada penelitian ini juga dilakukan secara kualitatif dengan metode carik celup, bukan secara kuantitatif sehingga memungkinkan untuk mendapatkan hasil yang kurang sesuai. Pemeriksaan carik celup dapat memberikan hasil positif palsu apabila urin berada pada $\mathrm{pH}>7.0$. Hasil positif palsu dapat juga terjadi apabila urin dalam keadaan sangat pekat maupun pada urin yang terkontaminasi oleh darah. ${ }^{5}$ Pemeriksaan carik celup juga hanya dapat mendeteksi albumin pada urin sehingga proteinuria yang bukan dikarenakan oleh albumin menjadi tidak terdeteksi oleh pemeriksaan carik celup. ${ }^{5}$ Hal tersebut dapat berpengaruh terhadap hasil penelitian.
Desain penelitian berupa cross-sectional merupakan desain yang sulit untuk menentukan sebab dan akibat dikarenakan pengambilan sampel yang dilakukan pada satu waktu yang bersamaan sehingga desain ini tidak tepat jika digunakan pada penelitian yang membutuhkan waktu cukup lama atau bersifat korelatif.

Pemilihan metode pengukuran, serta metode penelitian yang dipakai menjadi keterbatasan dalam penelitian ini sehingga hasil yang didapatkan tidak bermakna secara statistik. Diharapkan pada penelitian lebih lanjut dapat menggunakan metode penelitian dan pengukuran yang berbeda untuk memperoleh hasil yang lebih baik.

\section{Kesimpulan}

Tidak terdapat hubungan antara kadar HbA1c dan fungsi ginjal berdasarkan LFG dan proteinuria pada penderita Diabetes Melitus Tipe 2.

\section{Daftar Pustaka}

1. Kementerian Kesehatan Republik Indonesia. Penyakit tidak menular. Buletin Jendela Data dan Informasi Kesehatan. Jakarta: Kementerian Kesehatan Republik Indonesia; 2012.

2. Soegondo S, Soewondo P, Subekti I, editors. Penatalaksanaan diabetes melitus terpadu. 2nd ed. Jakarta: Balai Penerbit FK UI; 2011. h. 3-29.

3. International Diabetes Federation. IDF Diabetes atlas. 7th Edition. Dunia: International Diabetes Federation; 2015.

4. David L, Cecillia L, Simon C, Laurence K. Diabetes: clinican's desk reference. London: Manson Publishing Ltd; 2012.

5. Dan L, Eugene B, Stephen L, Jameson J. Harrison: Principles of internal medicine. New York: McGraw-Hill; 2015.

6. Nandhita, Arun, et al. Diabetes in asia pasific: Implcation for the Global Epidemic. Diabetes Care; 2016.

7. Laporan Hasil Riset Kesehatan Dasar 2013. Jakarta: Kementrian Kesehatan RI; 2013.

8. Purnamasari ,E, Poerwantoro, B. Laporan kasus: diabetes mellitus dengan penyulit kronis. Majalah Kesehatan PharmaMedika. 2011;3(2):276-81.

9. Peraturan Menteri Kesehatan Republik Indonesia Nomor 5 Tahun 2014. Panduan praktek klinis bagi dokter di fasilitas pelayanan kesehatan primer. Jakarta: Kementerian Kesehatan Republik Indonesia; 2014.

10. Snell, Richard S. Anatomi klinis berdasarkan sistem. Jakarta: EGC; 2011.

11. Sajan MP, Farese RV. Insulin signaling in hepatocytes of humans with type 2 diabetes: excessive production and activity of protein kinase c-iota (pkc-iota) and dependent processes and reversal pkc-iota inhibitors. Diabetologia. 2012;55(5):1446-57.

12. Sopiyudin, M. Dahlan. Statistik untuk kedokteran dan 
kesehatan, Edisi 6 deskriptif, bivariat, dan multivariat, dilengkapi dengan aplikasi dengan menggunakan SPSS. Jakarta: Salemba Medika; 2013.

13. Gahung R, Pandelaki K, Moeis ES. Hubungan kadar HbA1c dengan estimasi filtrasi glomerulus pada pasien DM Tipe 2. Jurnal e-CliniC (eCl). 2016;4(1).
14. American Diabetes Association. Classification and Diagnosis of Diabetes. Diabetes Care; 2015. h. 8-16.

15. Guyton AC, Hall JE. Textbook of medical physiology. 12th ed. Philadelphia: Elsevier Saunders; 2013. h. 626-39. 